\title{
Histopathological Alterations in the Gills and Liver of Clarias Gariepinus Juveniles Exposed to Acute Concentrations of Anogeissus Leiocarpus
}

\author{
Bala Sambo Audu ${ }^{1, *}$, Idris Audu Wakawa², Omirinde Jamiu Oyewole ${ }^{3}$ and Ponwa \\ Zingfa Changdaya $^{1}$ \\ ${ }^{1}$ Hydrobiology and Fisheries Unit, Department of Zoology, University of Jos, Jos, Nigeria; ${ }^{2}$ Department of Biology, Umar Suleiman College \\ of Education, Gashua, Yobe State, Nigeria $;^{3}$ Department of Anatomy, Faculty of Veterinary Medicine, University of Jos. Nigeria.
}

Received: August 12, 2020; Revised: November 25, 2020; Accepted: December 12, 2020

\begin{abstract}
Over the years, people have used the stem bark extract of Anogeissus leiocarpus in traditional tanneries as a native agent in tendering hide and skin. The wastes from the processing plant are washed into aquatic environment and cause pollution. The acute toxicity $\left(96 \mathrm{hr}-\mathrm{LC}_{50}\right.$ ) of the aqueous crude stem extract of $A$. leiocarpus on behaviour and histopathology of gills and liver of Clarias gariepinus juveniles (average weight $42.00 \pm 0.05 \mathrm{~g}$ and average total length $27.83 \pm 0.71 \mathrm{~cm}$ ) were investigated in a static non-renewable bioassay to ascertain its toxicity. A total of five concentrations of aqueous crude stem extract of A. leiocarpus (450.00, 400.00, 350.00, 300.00, and $250.00 \mathrm{mg} / \mathrm{L})$ and a control $(0.00 \mathrm{~g} / \mathrm{L})$ were used. Ten (10) juveniles were stocked in each tank with dimension of 50x30x25 cm. Of the one hundred and twenty (120) mixed sex $C$. gariepinus juveniles (in duplicate replication) used, mortalities of 100, 70, 50, 20, and 10\% were recorded in concentrations 450.00, 400.00, 350.00, 300.00, and $250.00 \mathrm{mg} / \mathrm{L}$ respectively while control recorded $0 \%$ after $96 \mathrm{hr}$. The $96 \mathrm{hr}$. $\mathrm{LC}_{50}$ of $A$. leiocarpus on C. gariepinus resulted in $353.77 \mathrm{mg} / \mathrm{L}$ characterized by upper and lower confidence limits of 390.27 and $320.69 \mathrm{mg} / \mathrm{L}$ respectively. There was marked variation in the water quality parameters (total alkalinity and free carbon dioxide) in all the test tanks compared with the control. The behavioural signs exhibited by C. gariepinus exposed to concentrated grades of the plant material were erratic swimming, loss of stability, spiral movement, air gulping, restlessness and settling on tank bottom. Histopathological alterations such as lamellar vascular congestion, lamellar clubbing and partial to complete inter-lamellar space occlusion were recorded in the gills of Clarias gariepinus exposed to the graded concentrations of the extract. The liver of the catfish showed dose-related hepatic lesions such as portal congestion, periportal cellular degeneration and cellular infiltration. This study shows that 300.00 to $450.00 \mathrm{mg} / \mathrm{L}$ of A. leiocarpus is toxic to fish's health. Hence its indiscriminate disposal into aquatic environment should be discouraged or totally avoided to avert death of aquatic animals.
\end{abstract}

Keywords: Acute toxicity; Histopathology; Anogeissus leiocarpus; Clarias gariepinus

\section{Introduction}

Anogeissus leiocarpus, commonly known as African birch, is a deciduous tall plant found in the tropical Africa (Steentoft, 1988). It grows continually to attain a height of $15-18.0 \mathrm{~m}$ with the stem measuring about $1 \mathrm{~m}$ in diameter (Arbab, 2014). The bark of A. leiocarpus is grayish and rough while leaves are alternate, ovate to lanceolate shape with length-width dimensions of $2.0-8.0 \mathrm{~cm}$ and $1.3-5.0$ cm respectively (Mbagwu, 2011). Small branches of $A$. leiocarpus are crushed to make dyes in tanning skin while decoction of the bark is reputed man and farm animals antihelmintics as well as potent antiprotozoans against malaria and trypanosomiasis in animals (Arbonnier, 2004; Okpekon, 2004). The sticks are chewed into fibrous brush to clean teeth by rural population in Nigeria (Rotimi, 1988).

\footnotetext{
* Corresponding author e-mail: audusambo@yahoo.com.
}

Plants constitute an unlimited origin of a variety of biological active substances (Istvan, 2000) which have toxic effects on the aquatic biota. Artisanal fishermen use plant extract as part of their arsenal of fishing tools (Power et al., 2010). Extracts of plants such as Blighia sapda, Kigelia africana, Raphia, vinifera (Omoitoyin et al., 1999), Derris elliptica, Tephrosia vogelli (Oluwatoyin, 2011) and Balanites aegyptiaca (Wakawa et al., 2018) have been reported to be used by fishermen as fishing tool. These plant extracts used in harvesting fish have toxic properties (Fafioye et al., 2004) that paralyze or stupefy fish (Fafioye, 2011) in the aquatic environment. Examination of the phytochemicals of plants used as fish poison shows the presence of saponins, alkaloid and flavonoids (Fafioye, 2011). Others are tannins, resins, terpens, cardiac glycosides and balsam (Wakawa et al., 2018). Saponins affect haematology and oxygen uptake of fish (Roy and Munshin, 1989) while alkaloid and flavonoids have anaesthetic properties on fish (Tsuchiya, 
2017). Stem bark of A. leiocarpus contains phytochemicals such as tannins, flavonoids, terpens and saponins with absence of alkanoids and anthraquinones (Salau et al., 2013). Introduction of plant extracts containing these phytochemicals could result into physiological stress in aquatic biota which could ultimately reduce aquatic productivity (Oluwatoyin, 2011) or even death.

In view of the effect of the plant extracts used in harvesting fish, many workers have assessed the acute toxicity performance of biosynthetic chemicals of plant origin to cause disease conditions in tissues/organs, serum biochemistry and haematology of different fish species. Audu et al. (2020) studied histopathological effects of unrefined water fractions of the foliage of Balanites aegyptiaca on gills, kidney and liver of Oreochromis niloticus fingerlings. Similarly, Audu et al. (2017) examined histological changes in gills and liver of $C$. gariepinus intoxicated with acute concentrated grades of Vernonia amygdalina. Also, Adesina et al. (2013) evaluated the effect of acute toxicity of Moringa oleifera root extract on $O$. niloticus. Nasiruddin et al. (2012) investigated the histological alterations in organs of Heteropneustes fossilis intoxicated with extracts of three dry seed, while Oluwatoyin (2011) studied the Ipomoea aquatica leaf extract toxic potential on histopathology of O. niloticus. Shahi and Singh (2011) investigated the effects of extracts of euphobious plants on serum biochemistry and haematology profiles of Channa punctatus. There is, however, paucity of data on acute toxicity of aqueous crude stem bark extract of $A$. leiocarpus on histopathology of $C$. gariepinus juveniles. Hence this study aimed at investigating the possibilities on behaviour and histopathology of gills and liver of $C$. gariepinus juveniles.

\section{Materials and Methods}

\subsection{Collection and Preparation of Stem Bark of Anogeissus leiocarpus}

A. leiocarpus stem bark (50 g) was collected from Hwol Yarje, Jos North Local Government, Plateau State, Nigeria. The plant was identified by a plant taxonomist as Anogeissus leiocarpus (DC.) Guill \& Perr; voucher number=JUHN20000324, mounted and deposited in the Herbarium of Plant Science and Technology Department, University of Jos, Nigeria. The stem bark was sheared from the tree plant using an axe and shade-dried over seven days with outdoor relative humidity of $57 \%$ and ambient temperature of $28^{\circ} \mathrm{C}$. The dried stem bark was pulverized in the laboratory using mortar and pestle into fine particles, sieved with a meshed utensil $(30 \mu \mathrm{m})$ and stored in airtight transparent polyethene bag for subsequent use.

\subsection{Laboratory Conditioning of Test Fish (Clarias gariepinus)}

Outright, one hundred and twenty (120) juveniles (69weeks old) of C. gariepinus (average weight $42.00 \pm 0.05$ $\mathrm{g}$ and average total length $27.83 \pm 0.71 \mathrm{~cm}$ ) were procured from a private fish farm at Kangang, Dadinkowa, Jos South were moved in three aerated cellophane bags (40 juveniles per bag) to the Zoology Department (Hydrobiology and Fisheries Laboratory Unit), University of Jos and stocked using 10 round plastic tanks of $20 \mathrm{~L}$ capacity (10 fish/tank) each filled with $15 \mathrm{~L}$ of dechlorinated municipal water. Commercial diet (Multifeeds ${ }^{\circledR}$ ) was given to fish twice daily on satiation basis and water in the holding tanks was changed once daily. Fish were allowed to acclimate for two weeks during this period; fish were held under natural photo regime (12 Light: 12 Dark) (Bala et al., 2014).

\subsection{Experimental Design}

Sequel to acclimation period, fish were divided into experimental tanks which consists of twelve (12) rectangular plastic tanks $(50 \times 30 \times 25 \mathrm{~cm})$ and $120 \mathrm{C}$. gariepinus juveniles arranged in a randomized block design. All the tanks contained ten $(10 \mathrm{~L})$ liters each of chloric-free pipe borne water, with five (5) of the test tanks exposed to varying concentrations (450.00, 400.00, $350.00,300.00$ and $250.00 \mathrm{mg} / \mathrm{L}$ ) of the aqueous stem bark extract of A. leiocarpus. Ten (10) C. gariepinus juveniles each were introduced into all the five (5) test and control tanks. The sixth tank served as the control and was not inoculated with the test material $(0.00 \mathrm{mg} / \mathrm{L})$. The setup was replicated twice.

\subsection{Acute toxicity test}

Static non-renewal bioassay technique (USEPA, 1985) was used for the $96 \mathrm{hr}$. $\mathrm{LC}_{50}$ experiment. The aqueous stem extract was obtained by macerating two (2) grams of the finely grinded particles of stem bark of $A$. leiocarpus in distilled water for 24 hours under room $\left(25^{\circ} \mathrm{C}\right)$ condition from which graded concentrations of 450, 400, 350, 300, and $250.00 \mathrm{mg} / \mathrm{L}$ were obtained through serial dilution of the stock after range finding tests. The control tank $(0.00 \mathrm{mg} / \mathrm{L})$ did not contain the test plant. The test tanks with the definitive concentrated grades of the plant extract and the control tanks were each duplicated replicated, stocked with ten (10) juveniles per tank and were devoid of artificial aeration and feeding throughout the 96 hours experiment.

\subsection{Aquatic medium quality analysis}

Physicochemical parameters including dissolved oxygen (DO), temperature, free carbon (iv) dioxide $\left(\mathrm{CO}_{2}\right)$, hydrogen ion concentration $(\mathrm{pH})$ and total alkalinity (TA) were monitored every day as described by the American Public Health Association (APHA) (1985) techniques for water quality for fish culture throughout the experimental phase.

\subsection{Histopathological Examination}

Fish from each of the test concentrations (450.00.00, 400.00, 350.00, 300.00 and $250.00 \mathrm{mg} / \mathrm{L}$ ) were sacrificed and dissected to excise gills and liver. Excised organs were carefully washed of blood stains and kept in specimen bottles containing $0.005 \mathrm{~L}$ formal saline (Audu et al., 2017). Histopathological examinations were conducted at the central diagnostic unit of National Veterinary Research Institute (NVRI) Vom, Plateau State, Nigeria. Routine paraffin wax method and haematoxylin-eosin staining technique of tissue processing described by Drury and Wallington (1967) and Avwioro (2011) were adopted for the examinations of the excised organs (gills and liver) of C. gariepinus exposed to aqueous crude stem bark extract of A. leiocarpus. 


\subsection{Statistical Analyses}

Water quality parameters were analysed using IBM SPSS (version 20) software. The Analysis of Variance (ANOVA) was used to establish significant differences. The Tukey test was used to separate treatment means while level of significance was determined at $\alpha_{0.05}$.

\section{Results}

3.1. Mean Water Quality Parameters of Tanks with Clarias gariepinus exposed to Acute Concentrations of Anogeissus leiocarpus

Water quality parameters in the $96 \mathrm{hr}$ acute bioassay of A. leiocarpus extract on $C$. gariepinus juveniles are summarized in Table 1. Temperature, DO and $\mathrm{pH}$ decreased as the toxicant concentration increased while free $\mathrm{CO}_{2}$ and TA correspondingly rose with elevated toxicant concentrations. $\mathrm{P}$-value of significance $(\mathrm{p}<0.05)$ was obtained for TA and free $\mathrm{CO}_{2}$ in the test tanks compared to the control group.

\subsection{Behavioural Patterns of Clarias gariepinus Juveniles during $96 \mathrm{hr}$ Acute Toxicity Test with Extract of Anogeissus leiocarpus}

Fish exposed to the plant extract showed behavioural patterns such as erratic movement, loss of stability and spiral movement. Fish settled at the bottom of the tank and remained motionless for a while and sudden frequent swimming to the water surface to gulp air. After prolonged exposure (> $48 \mathrm{hr}$.) the fish skin peeled off and the fish gradually became weak, and finally death occurred. Fish was considered dead when there was permanent cessation of spontaneous movement and a failure to react to strong external stimulation probe made of glass rod. The death of the juveniles was directly concentration- dependent in relation to exposure time. At the highest plant extract concentration ( $400.00 \mathrm{mg} / \mathrm{L})$, mortality was within $24 \mathrm{hr}$ exposure while in the lower concentrations (300.00 and $350.00 \mathrm{mg} / \mathrm{L}$ ) mortality resulted after $48 \mathrm{hr}$ exposure of the juveniles to the plant extract. In the lowest concentrations $(250.00 \mathrm{mg} / \mathrm{L})$ of the plant extract, death of juveniles was recorded after $72 \mathrm{hr}$ of exposure to the plant extract (Table 2).

Table 1. Mean Water Quality Parameters of Acute Bioassay of Crude Stem Bark Extracts of Anogeissus leiocarpus on Clarias gariepinus Juveniles

\begin{tabular}{|c|c|c|c|c|c|c|}
\hline \multirow{2}{*}{$\begin{array}{l}\text { Water Quality } \\
\text { Parameters }\end{array}$} & \multicolumn{6}{|c|}{ Concentration (mg/L) } \\
\hline & 0.00 & 250.00 & 300.00 & 350.00 & 400.00 & 450.00 \\
\hline Temp. $\left({ }^{\circ} \mathrm{C}\right)$ & $25.5 \pm 0.00$ & $24.60 \pm 0.28$ & $24.20 \pm 0.28$ & $24.40 \pm 0.07$ & $24.40 \pm 0.28$ & $24.20 \pm 0.14$ \\
\hline DO (mg/L) & $2.20 \pm 0.00$ & $1.90 \pm 0.00$ & $1.90 \pm 0.00$ & $1.70 \pm 0.00$ & $1.50 \pm 0.14$ & $1.45 \pm 0.07$ \\
\hline TA (mg/L) & $60.50 \pm 0.00$ & $68.85 \pm 0.07 *$ & $74.90 \pm 0.71 *$ & $85.00 \pm 12.73 *$ & $114.50 \pm 0.71^{*}$ & $220.10 \pm 0.14^{*}$ \\
\hline $\mathrm{pH}$ & $7.35 \pm 0.07$ & $7.20 \pm 0.00$ & $7.25 \pm 0.07$ & $7.20 \pm 0.00$ & $7.20 \pm 0.07$ & $7.10 \pm 0.14$ \\
\hline Free $\mathrm{CO}_{2}(\mathrm{mg} / \mathrm{L})$ & $34.00 \pm 0.00$ & $49.00 \pm 0.00 *$ & $49.60 \pm 0.85 *$ & $54.30 \pm 4.94 *$ & $60.00 \pm 2.83 *$ & $68.00 \pm 0.00 *$ \\
\hline
\end{tabular}

Values with Asterisks (*) in the same Row are Significantly Different Compared with the Control

TA= Total Alkalinity 
Table 2. Behavioural Patterns shown by Clarias gariepinus Juveniles exposed to Aqueous Crude Stem Bark Extract of $A$. leiocarpus

\begin{tabular}{|c|c|c|c|c|}
\hline \multirow[t]{2}{*}{$\begin{array}{l}\text { Concentration } \\
\mathrm{mg} / \mathrm{L}\end{array}$} & \multirow[t]{2}{*}{ Behavioural Patterns } & \multicolumn{3}{|c|}{ Exposure Period (Hours) } \\
\hline & & 24 & 48 & 72 \\
\hline \multirow[t]{7}{*}{450} & Erratic swimming & +++ & ++ & + \\
\hline & Loss of stability & + & + & + \\
\hline & Air gulping & +++ & ++ & ++ \\
\hline & Spiral motion & - & + & + \\
\hline & Inactivity & - & + & ++ \\
\hline & Peeling of skin & + & ++ & +++ \\
\hline & Death & + & ++ & +++ \\
\hline \multirow[t]{7}{*}{400} & Erratic swimming & +++ & ++ & + \\
\hline & Loss of stability & + & + & + \\
\hline & Air gulping & ++ & ++ & ++ \\
\hline & Spiral motion & - & + & + \\
\hline & Inactivity & - & ++ & ++ \\
\hline & Peeling of skin & - & + & +++ \\
\hline & Death & + & + & ++ \\
\hline \multirow[t]{7}{*}{350} & Erratic swimming & + & ++ & ++ \\
\hline & Loss of stability & - & ++ & ++ \\
\hline & Air gulping & + & + & ++ \\
\hline & Spiral motion & - & ++ & ++ \\
\hline & Inactivity & - & - & + \\
\hline & Peeling of skin & - & - & + \\
\hline & Death & - & - & + \\
\hline \multirow[t]{7}{*}{300} & Erratic swimming & + & ++ & ++ \\
\hline & Loss of stability & - & ++ & ++ \\
\hline & Air gulping & + & + & ++ \\
\hline & Spiral motion & - & ++ & ++ \\
\hline & Inactivity & - & - & + \\
\hline & Peeling of skin & - & - & + \\
\hline & Death & - & - & + \\
\hline \multirow[t]{7}{*}{250} & Erratic swimming & - & + & + \\
\hline & Loss of stability & - & + & + \\
\hline & Air gulping & - & + & + \\
\hline & Spiral motion & + & + & + \\
\hline & Inactivity & - & - & - \\
\hline & Peeling of skin & - & - & - \\
\hline & Death & _ & - & _ \\
\hline
\end{tabular}

96 hr (LC50) Acute Bioassay of Extract of Anogeissus leiocarpus on Survival of Clarias gariepinus Juveniles

The effect of 96 hr $\mathrm{LC}_{50}$ acute bioassay of the extract of A. leiocarpus on survival of $C$. gariepinus juveniles is shown in Table 3. Survivals of the juveniles depend on the concentration of the extract. The rate of survival increased with decrease in the aqueous crude stem extract concentration. Recorded mortalities were 100, 70, 50, 20 and $10 \%$ of the plant extract concentrations 450.00 , 400.00, 350.00, 300.00 and $250.00 \mathrm{mg} / \mathrm{L}$ respectively. The control tank (0.00 mg/L) recorded 0\% mortality.

\subsection{Linear Relationship Between Mean Probit Mortality} Versus Log Concentration of C. gariepinus Juveniles exposed to Extract of Anogeissus leiocarpus

Figure 1 shows the linear relationship between mean probit mortality and log concentration of $C$. gariepinus juveniles exposed to the extract of $A$. leiocarpus. The $96 \mathrm{hr}$ $\mathrm{LC}_{50}$ of $A$. leiocarpus on $C$. gariepinus resulted in 353.77 $\mathrm{mg} / \mathrm{L}$ characterized by upper and lower confidence limits of 390.27 and $320.69 \mathrm{mg} / \mathrm{L}$ respectively.

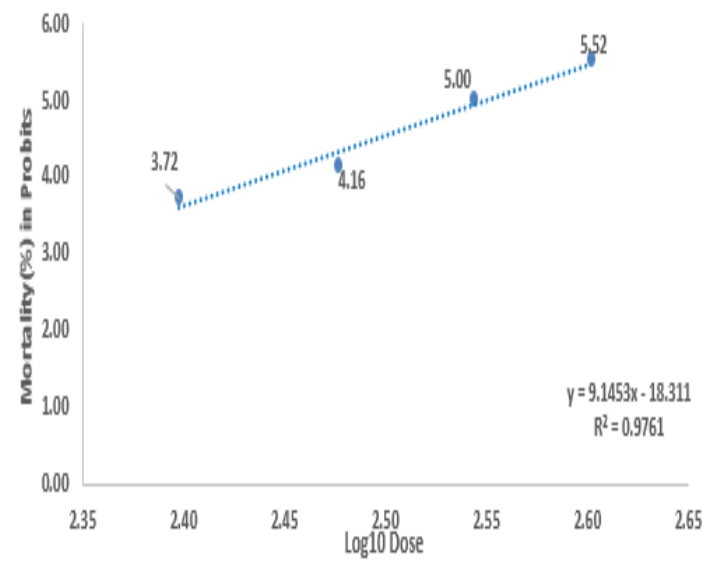

Figure 1. Linear Relationship between Mean Probit Mortality and Log Concentration of Clarias gariepinus Juveniles Exposed to Aqueous Crude Stem Bark Extract of Anogeissus leiocarpus

Table 3. Effects of Acute Bioassay of Aqueous Crude Stem Bark Extract of A. leiocarpus on Survival of Clarias gariepinus Juveniles

\begin{tabular}{|c|c|c|c|c|c|c|c|c|c|c|c|c|c|}
\hline \multirow{2}{*}{$\begin{array}{l}\text { Conc. } \\
\text { (mg/L) }\end{array}$} & \multirow{2}{*}{$\begin{array}{l}\text { Log } \\
\text { Conc. } \\
\end{array}$} & \multirow{2}{*}{$\begin{array}{l}\text { No. of } \\
\text { fish }\end{array}$} & \multicolumn{8}{|c|}{ Mortality Time (Hours) } & \multirow{2}{*}{$\begin{array}{l}\text { Total } \\
\text { Dead }\end{array}$} & \multirow{2}{*}{$\begin{array}{l}\text { Mortality } \\
(\%)\end{array}$} & \multirow{2}{*}{$\begin{array}{l}\text { Probit } \\
\text { Mortality }\end{array}$} \\
\hline & & & 12 & 24 & 36 & 48 & 60 & 72 & 84 & 96 & & & \\
\hline 450.00 & 2.6532 & 10 & 3.50 & 2.50 & 1.50 & 1.00 & 1.00 & 1.00 & 0.50 & 0.00 & 10 & 100 & 8.7190 \\
\hline 400.00 & 2.6020 & 10 & 2.00 & 1.50 & 0.50 & 1.50 & 0.50 & 0.50 & 0.00 & 0.50 & 7 & 70 & 5.5244 \\
\hline 350.00 & 2.5440 & 10 & 0.00 & 0.00 & 1.00 & 0.50 & 0.50 & 0.50 & 0.00 & 1.00 & 5 & 50 & 5.0000 \\
\hline 300.00 & 2.4771 & 10 & 0.00 & 0.00 & 0.00 & 1.50 & 0.00 & 0.00 & 0.00 & 0.50 & 2 & 20 & 4.1584 \\
\hline 250.00 & 2.3979 & 10 & 0.00 & 0.00 & 0.00 & 0.00 & 0.00 & 0.50 & 0.5 & 0.00 & 1 & 10 & 3.1784 \\
\hline 0.00 & 0.0000 & 10 & 0.00 & 0.00 & 0.00 & 0.00 & 0.00 & 0.00 & 0.00 & 0.00 & 0 & 0 & 0.0000 \\
\hline
\end{tabular}

3.4. Histopathology of Gills of Clarias gariepinus Juveniles

Photomicrograph of effects of $96 \mathrm{hr}$ acute concentrations of extract of $A$. leiocarpus on gills of juveniles of $C$. gariepinus are presented in Plate 1 A-F. The gills of the control (Plate 1A) appear morphologically normal with typical structural organization of primary and secondary lamellae. There were progressive dose- dependent gill branchial-lamella injuries typified by slight (Plate 1B) to heavy vascular congestion and clubbing of the lamellae, partial to complete interlamellar space occlusion and lamellar cell hyperplasia. The gravity of the tissue distortion seemed to be more visible in the gill anatomical structure of juveniles treated with concentrations of $300.00,350.00,400.00$, and 450.00 $\mathrm{mg} / \mathrm{L}$ of the plant extract (Plates C-F). The histo- 
architecture of $C$. gariepinus intoxicated with the 250.00 $\mathrm{mg} / \mathrm{L}$ of the extract appeared to be normal when compared to the control.

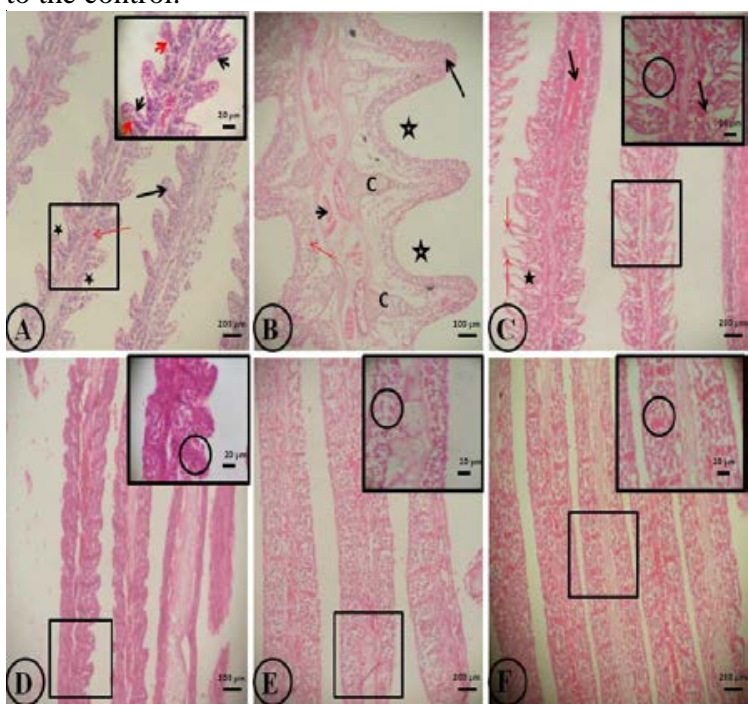

Plate 1.Light micrographs of the Gills of Clarias gariepinus Exposed to Acute Concentrations of Aqueous Crude Stem Bark Extract of Anogeissus leiocarpus. A. Control (0.00 $\mathbf{~ m g} / \mathbf{L})$ normal gill parenchyma typified by occurrence of structures like primary (red arrow) and secondary lamellae (black arrow), distinct epithelial (short black arrow) and pillar cells (short red arrow) of the secondary lamellae and patent inter-lamellar space or water channel (star). B. $\mathbf{2 5 0 . 0 0} \mathbf{~ m g / L}$ : Normal parenchyma as revealed by intact primary and secondary (red and black arrows respectively) lamellar epithelium and water channels (star) except for mild lamellar vascular congestion (short black arrow) C. $300.00 \mathrm{mg} / \mathrm{L}$ : Apical lamellar clubbing (red arrow), moderate lamellar cell fusion with partial to complete interlamellae space occlusion (star and circle outline (within inset) respectively), severe lamellar vascular congestion (black arrow) D. 350.00 mg/L: Severe hyperplastic lamellar cell with total disappearance of water channels (oval-outline). E. $400.00 \mathrm{mg} / \mathrm{L} ;$ F. 450.00 mg/L: Severe lamellar cell hyperplasia with complete interlamellar space occlusion (oval outlines within inset).

\subsection{Histopathology of Liver of Clarias gariepinus} Juveniles

Histopathological lesions noticed in the $C$. gariepinus liver exposed to acute concentrated grades of crude extract of A. leiocarpus are presented in Plate 2 A-F. The histopathological features of liver of C. gariepinus juveniles in the non-exposed (control) group include normal hepatic histo-architecture characterized by polyhedral outline and roundish nuclear, sinusoidal space and central veins; while, in C. gariepinus groups exposed to various concentrations of $A$. leiocarpus, the liver displayed increase in severity of histopathological lesions as concentration of the plant extract increased. Histopathological lesions observed in the treatment groups include moderate to severe portal congestion, periportal cellular degeneration, cellular infiltration and complete hepatocellular depletion.

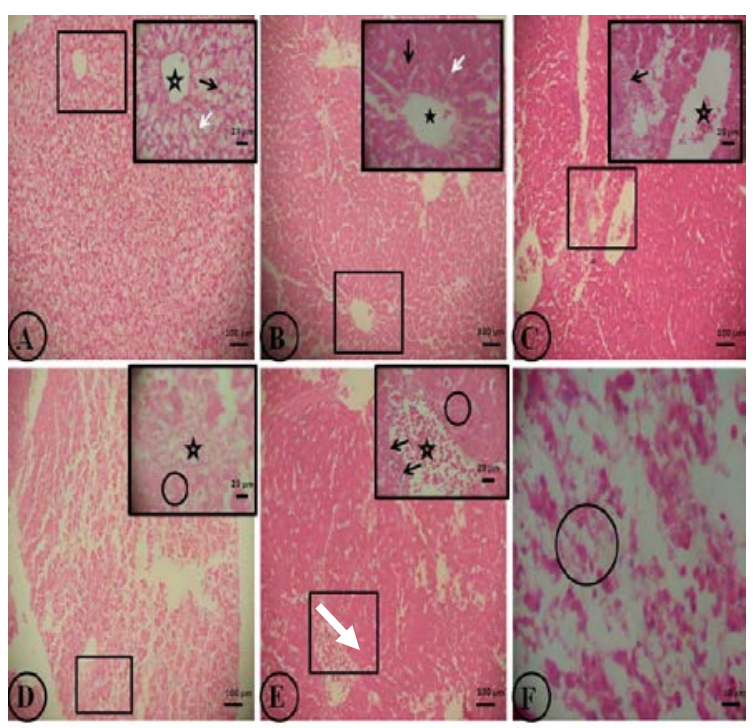

Plate 2. Light micrographs of the Liver of Clarias gariepinus Exposed to Acute Concentrations of Aqueous Crude Stem Bark Extract of Anogeissus leiocarpus A. Control (0.00 $\mathbf{~ m g / L ) : ~ n o r m a l ~}$ hepatic histo-architecture as revealed by hepatocytes with typical polyhedral outline and roundish nuclear (black arrow), sinusoids space (white arrows) and central vein (star). B. $250.00 \mathrm{mg} / \mathbf{L}$ : no visible lesion as evidenced by liver with intact hepatocyte (black arrow), sinusoids space (white arrow) and central vein (star) $\mathbf{C}$. 300.00 mg/L: visible lesion except for moderate sinusoidal congestion (black arrow). D. $\mathbf{3 5 0 . 0 0} \mathbf{~ m g / L}$ : moderate portal congestion (star) and peri-portal cellular degeneration (circle outline). E. $\mathbf{4 0 0 . 0 0} \mathbf{~ m g / L : ~ s e v e r e ~ p o r t a l ~ c o n g e s t i o n ~ ( s t a r ) , ~ m a r k e d ~}$ peri-portal cellular infiltration (arrow) and peri-portal cellular degeneration (circle outline) F. 450.00 mg/L: Severe hepatocellular depletion (circle outline).

\section{Discussion}

Determination of water quality parameters in fish culture during an experiment is necessary owing to the complete dependent nature of the whole life process of fish on the quality of the immediate surroundings (Bolorunduro and Abdullahi, 1996). Water quality is determined to confirm whether it plays any role in the alterations observed during the experiment as decline in water quality influences stress and disease in fish (Devi et al., 2017). The concentration-dependent decrease in DO in this study corroborates the findings of Makori et al. (2017). The minimum DO requirement of fish is $3.00 \mathrm{mg} / \mathrm{L}$ (Makori et al., 2017); therefore, the minimum mean DO (1.45 \pm 0.07 $\mathrm{mg} / \mathrm{L}$ ) in this study could be attributed to the presence of the plant extract in the water (Adebola and Ayo, 2014). The $\mathrm{pH}$ range (7.10 $\pm 0.14-7.25 \pm 0.07)$ in treatment tanks of this study is within the tolerable limits of catfish since the optimum $\mathrm{pH}$ for their survival is between 5 and 8 (Nobre et al., 2014); therefore, the $\mathrm{pH}$ in this study could not have affected the recorded mortalities in the tes ${ }^{+}$animal. Similarly, the recorded temperature range (24.20 \pm 0.14 $24.60 \pm 0.28{ }^{\circ} \mathrm{C}$ ) in treatment tanks falls within the standard range $\left(20-35{ }^{\circ} \mathrm{C}\right)$ documented by Ngugi et al. (2007), hence temperature could not have influenced the observed distortion in the histology of organs (gills and liver) of $C$. gariepinus. The TA which measures water productivity shows that the water tainted with the plant extract in this study is productive since the TA range (68.85 \pm 0.07 - 
$220.10 \pm 0.14 \mathrm{mg} / \mathrm{L})$ is within the productive $(50-500 \mathrm{mg} / \mathrm{L})$ level (Devi et al., 2017).

The abnormal behavioural patterns such as erratic movement, loss of stability, spiral movement and air gulping displayed by C. gariepinus juveniles in the higher treatment concentrations (350.00, 400.00 and 450.00 $\mathrm{mg} / \mathrm{L}$ ) of the aqueous stem bark extract could be due to the fish's deliberate effort to overcome the toxic plant bioactive substances and the hypoxic condition possibly caused by the aqueous stem bark extract of A. leiocarpus. The manifested behavioural patterns have earlier been linked to derangement in the biochemical and nervous systems of the stressed fish (Fadina et al., 1991; Fafioye et al., 2005). In addition, the dose-related increase in the mortality rate seen in this study further established the toxic nature of Anogeissus leiocarpus. The trends of behavioural signs and the mortality rate shown by fish exposed to graded concentrations of A. leiocarpus are similar to those documented for Trephosia vogelii (Adewoye, 2010), Parkia biglobosa (Ojutiku et al., 2012), Carica papaya (Eyo et al., 2013), and Vernonia amygdalina (Audu et al., 2017).

Histological distortions have been extensively optimized as biomarkers of pollutants in fish (Naeemi et al., 2013). Gill of fish plays important function including respiration, osmoregulation and excretion (Camargo and Martinez, 2007; Jalaludeen et al., 2012; Audu et al., 2017) due to its contact with the immediate water environment (Olojo et al., 2005). This proximity with the external environment predisposes it to histological damages such that the fish becomes vulnerable to respiratory and osmoregulatory difficulties (Olusegun and Adedayo, 2014) especially when toxicants enter the body and cause damage to gill membranes and affect its physiological functions (Bala and Malachy 2020). Succinctly put, fish exposed to toxicants die when their gill lamella epithelia and blood vessels are adversely affected (Hinton and Lauren, 1990).

Therefore, the observed moderate to severe gill histoarchitectural alterations (lamellar vascular congestion, lamellar clubbing, partial to complete inter-lamellar space occlusion and lamellar cell hyperplasia) in this study further established the toxic potential of A. leiocarpus extract. The gill histopathogical profiles in this study corroborate lesions earlier reported in similar studies conducted by Camargo and Martinez (2007) in Neotropical fish caught from stream laden with toxicant and the histopathological report of Nasiruddin et al. (2012) on Heteropneustes fossilis exposed to three dried leaves extracts.

The detoxification and biotransformation processes are reputed functions of the liver which has directly placed it as most morpho-physiologically disrupted organ by contaminants in the water (Hadi and Alwan (2012). With respect to these physiological roles, the histopathological alterations (moderate to severe portal congestion, periportal cellular degeneration, cellular infiltration and complete hepatocellualar depletion) shown by $C$. gariepinus exposed to graded concentrations of $A$. leiocarpus could precipitate serious hepatic dysfunction. The dose-related disruption in the liver parenchyma of $C$. gariepinus juveniles has earlier been credited to extreme physiological activities needed by the fish to excrete the toxic substances out of its body during detoxification and biotransformation processes (Adebola and Ayo, 2014). However, further studies that will incorporate liver enzymes profiles and anti-oxidant assays will be necessary to reveal the impact of the extract (aqueous stem bark) of A. leiocarpus on C. gariepinus liver physiology.

\section{Conclusion}

This study has demonstrated that aqueous crude stem bark extract of A. leiocarpus has deleterious and piscicidal effects on C. gariepinus juveniles, hence its washing, processing and indiscriminate disposal into aquatic environments should be discouraged or totally avoided to preserve aquatic biodiversity and abundance particularly of fish species such as tropical freshwater African catfish $C$. gariepinus.

\section{Acknowledgement}

The authors are appreciative of the laboratory space provided by the Department of Zoology, University of Jos for the conduction of the experiment and for the expertise rendered by the technical staff of the Central Diagnostic Unit of National Veterinary Research Institute, Vom, Plateau State, Nigeria.

\section{References}

Adebola K and Ayo F. 2014. Histological changes in liver, gills and kidney of catfish (Heterobranchus bidorsalis) exposed to cypermethrin concentration. Int. J Histol .Cytol., 1: 31-36.

Adesina BT, Omitoyin BO, Ajani EK and Adesina OA. 2013. Acute-lethal toxicity $\left(\mathrm{LC}_{50}\right)$ of Moringa oleifera (Lam.) fresh root bark extract on Oreochromis niloticus juveniles under renewal toxicity exposure. Int. J Appl. Agric. Apicu. Res., 1: 182-188.

Adewoye SO. 2010. Haematological and biochemical changes in Clarias gariepinus exposed to Trephosia vogelii extract. Adv. Appl. Sci. Res., 1(1): 74 - 79.

APHA (American Public Health Association) 1985. Standard Methods for Examination of Water and Wastewater. Washington. USA. Pp: 258-259.

Arbab AH. 2014. Review on Anogeissus leiocarpus a potent African traditional drug. Int. J Res. Pharm. Chem., 4: 496-500.

Arbonnier M. 2004. Trees, Shrubs and Lianas of West African Dry Zones. The Netherlands: Cirad Margraf. Pp. 573.

Audu BS, Omirinde JO, Gosomji IJ and Wazhi PE. 2017. Histopathological changes in the gill and liver of Clarias gariepinus exposed to acute concentrations of Vernonia amygdalina. Ani. Res. Int., 14: 2576-2587.

Audu BS, Wakawa IA, Omirinde JO, Garba U and Damshit M. 2020. Histopathological alterations in organs of Nile tilapia fingerlings exposed to sublethal concentrations of aqueous crude leaves extract of desert date. Pan Afri. J Life Sci., 4: 59-67.

Bala SA, Kabir MA and Paul CO. 2014. Biochemical Parameters of Common Carp (Cyprinus carpio) exposed to Crude Leaf Extract of Cannabis sativa. Jordan J Biol Sci., 7, 147 - 151. Cite score (0.47)

Bala SA and Malachy NOA. 2020 Metabolic enzyme profile, behavioural changes and morpho physiological parameters of African catfish Clarias gariepinus juveniles in response to burnt waste tyres. Comp Clin Pathol., 29:787-797. 
Bolorunduro PI and Abdullah AY. 1996. Water quality management in fish culture, national agricultural extension and research liaison services, Zaria, Extension Bulletin No. 98.

Camargo MMP and Martinez CBR. 2007. Histopathology of gills, kidney and liver of a neotropical urban stream. Neotrop Ichthyo., 5: 327-336.

Devi PA, Padmavathy P, Aanand S and Aruljothy K. 2017. Review on water quality parameters in freshwater cage fish culture. Int. J App. Res., 3: 114-120.

Drury R Wallington E. 1967. Histological Technique. 4th edition, Oxford University Press, USA, pp 279-280.

Eyo JE, Levi CA, Asogwa CN, Odii EC, Chukwuka CO, Ivoke N, Onoja US and Onyeke CC. 2013.

Toxicity and effect of Carica papaya seed aqueous extract on liver biomarkers of Clarias gariepinus. Int. J Indig. Med. Plant., 46(3): 1301 - 1307 .

Fadina OO, Taiwo VO. and Ogunsanmi AO. 1991. The effects of single and repetitive oral administration

of common pesticides and alcohol on rabbits. Trop Vet., 17: 97 106.

Fafioye OO, Fagade S O and Adebisi AA. 2005. Toxicity of Raphia vinifera, P. beauv fruit extracts

on biochemical composition of Nile tilapia (Oreochromis niloticus, Trewavas). Biokemistri., 17: 137 - 142.

Fafioye OO. 2011. Lethal and sublethal effects of plant extract on some freshwater fauna. PhD thesis, University of Ibadan, Nigeria.

Fafioye OO, Adebisis AA and Fagade SO. 2004. Toxicity of Parkia biglobosa (locust bean) and Raphia vinifera extracts on Clarias gariepinus juveniles. Afri. J Biotech., 3: 627-630.

Hadi AA and Alwan SF. 2012. Histopathological changes in gills, liver and kidney of fresh water fish, Tilapia zillii, exposed to aluminium. Int. J Pharm Life Sci.. 3: 2071-2051.

Istvan U. 2000. Semi-natural products and related substances as alleged botanical pesticides. Pest Manage. Sci., 56: 703-705.

Jalaludeen MD, Arunachalam M, Raja M, Nandagopal Bhat SA, Sundar S and Palannimuthu D. 2012. Histopathology of the gill, liver and kidney tissues of the freshwater fish Tilapia mossambica exposed to cadmium sulphate. Int. J Adv. Biol. Res., 2: 572-578.

Hinton DE and Laurén DJ. 1990. Liver structural alterations accompanying chronic toxicity in fishes: Potential Biomarkers of Exposure. In: McCarthy JF and Shugart LR (Eds.). Biomarkers of Environmental Contamination, Boca Raton: Lewis Publishers. pp. 51-65.

Makori AJ, Aboum PO, Kapiyo R, Ayona DN and Dida GO. 2017. Effects of water physico- chemical parameters on tilapia (Oreochromis niloticus) growth in earthen ponds in Teso North Sub-county, Busia county. Fish. Aqua. Sci., 20: 2-10.

Mbagwu ES. 2011. Acute toxicity of Persea americana crude seed extracts on the physiology and histopathology of Clarias gariepinus fingerlings under laboratory conditions. BSc project, University of Jos, Jos, Nigeria.

Naeemi A, Jamili S, Shabanipour N, Mashinchian A and Shariati FS. 2013. Histopathological changes of gill, liver, and kidney in Caspian kutum exposed to linear alkylbenzene. Iran J Fish. Sci., 12: 887-897.

Nasiruddin M, Azadi MA and Jahan A. 2012. Histopathological changes in gill, liver and intestine of Heteropneustes fossilis (bloch) treated with three dry seed extracts. $J$ Asia Soc Bangladash Sci., 38: 217-226.
Ngugi CC, James RB, and Bethuel OO. 2007. A New Guide to Fish Farming in Kenya, Oregon State University, USA. 95pp.

Nobre MKB, Lima FRS and Magalhaes FB.2014. Alternative liming blends for fish culture. Acta Sci. Ani. Sci., 36: 11-16.

Ojutiku, RO, Avbarefe EP, Kolo RJ and Asuwaju FP. 2012. Toxicity of Parkia biglobosa pod

extract on Clarias gariepinus juveniles. Int. J Fish. Aquac., 4(7): $133-138$.

Okpekon T. 2004. Antiparasitic activities of medicinal plants used in Ivory Coast. J Ethnopharm., 90: 91-97.

Olojo EAA, Olurin KB, Mbaka G and Oluwemimo AD. 2005. Histopathology of Gills and Liver Tissues of the African Catfish (Clarias gariepinus) exposed to Lead. Afri. J Biotech., 4: 117122.

Olusegun AA and Adedayo OO. 2014. Haematological responses, serum biochemistry and histology of Clarias gariepinus (Burchell, 1822) exposed to sublethal concentrations of cold water fresh root bark extracts of Plumbago zeylanica (leadwort). J. Aqua. Res. Dev., 5: 282-288.

Oluwatoyin AS. 2011. Histopathology of Nile tilapia (Oreochromis niloticus) juveniles exposed to aqueous and ethanolic extracts of Ipomoea aquatic leaf. Int. J Fish. Aquac., 3: 244-257.

Omoitoyin BO, Ogunsami AO and Adesina BT. 1999. Studies on acute toxicity of piscidal plants extract on tilapia (Sarotherodon galliceus) fingerlings. Tropic J Ani. Sci., 2: 191-197.

Power DM, Fuentes J, Harrison AP. 2010. “A noninvasive monitoring device for anaesthetics in fish" Dove press, http://www.dovepress.com (May 5, 2014).

Rotimi VO. 1988. Activities of Nigerian chewing stick extracts against Bacteroides gingivalis and Bacteroides melaninogenicus. Antimicrob Agents Chemothera., 32: 598-600.

Roy RK and Munshin DJ. 1989. Effects of saponin extracts in oxygen uptake and haematology of air brcathing climbina perch (Anabastes titutdines) (Bloch) J Fresh Water Biol., 1: 167-172.

Salau AK, Yakubu MT, Oladiji AT, 2013. Cytotoxic activity of aqueous extracts of Anogeissus leiocarpus and Terminalia avicennioides root barks against ehrlich ascites carcinoma cells. Indian J Pharm., 45: 381-385.

Shahi J and Singh A. 2011. Effect of bioactive compounds extracted from euphorbious plants on haematological and biochemical parameters of Channa punctatus. Rev Inst. Med. Tropic. Sao Paulo., 53: 259-263.

Steentoft M. 1988. Flowering plants in West Africa. Cambridge University Press. London UK. Pp234.

Tsuchiya H. 2017. Analgestic agents of plant origin. A review of phytochemicals with anaesthetic activity. Molecules., 22: 13691402.

USEPA 1985. Disciplinary Review Ecological Effects Profile. US Environmental Protection Agency, Office of Pesticide Programs, 401 M St. S.W., Washington DC 20460, USA.

Wakawa AI, Audu BS, Sulaiman Y. 2018. Phytochemistry and proximate composition of root, stem bark, leaf and fruit of desert date, Balanites aegyptiaca, J. Phytopharm. Pharmacog. Phytomed. Res., 7: 464-470. 